\title{
Identification of Refund of Excise Duty on Motor Oils for International Road Freight Transport
}

\author{
Miloš Poliak $^{1}$, Iwona Ewa Tomaszewska ${ }^{1}$, Marek Jaskiewicz ${ }^{2}$, Natalia A. Zhuravleva ${ }^{3}$, \\ Natalia Lakhmetkina ${ }^{4}$, Ekaterina Salamakhina ${ }^{1}$ \\ ${ }^{1}$ University Of Zilina, Univerzitná 1, 010 26, Žilina, Slovakia \\ ${ }^{2}$ Kielce University of Technology, Al. Tysiaclecia Panstwa Polskiego 7, 25-314 Kielce, Poland \\ ${ }^{3}$ State Transport University St. Petersburg Polytechnic University, Polytechnicheskaya 29, Russia \\ ${ }^{4}$ Russian University of Transport, Moscow, Russia
}

\begin{abstract}
In this article, the authors focus on the issue of refunding excise duty on motor oils within Europe . Some states have a refund in their legislation, most European countries do not, and this creates pressure from carriers to make decisions, where and how much it pays to refuel in your vehicles for international transportation. For this article, research was conducted in the field of research, analysis and comparison of conditions for creating a competitive environment within the countries of Europe. The article also wants to point out that the reimbursement is not subject to national transport, respectively. international transport and drawing by foreign carriers in countries where reimbursement is introduced are supported..
\end{abstract}

Keywords Refundation, Excise duty, Freight transport, Price

JEL H29, L91, R40

\section{Introduction}

Tax revenue from excise duty on mineral oils can be classified as one of the highest, which is credited to the state budget of the country. The amount of state budget revenue depends on the volume of fuel consumed. Income for a particular country is not dependent on the volume of fuel consumed in its territory, but on the volume of fuel used in that country. For this reason, individual EU countries, as the EU is a single customs territory, are based on two assumptions: if the price of fuels increases, the withdrawal to the state budget will increase; if the price of fuels increases, the demand for refuelling abroad will increase, where the price level is lower. EU legislation sets a minimum level of taxation of fuels in the EU through directives, but the maximum level of taxation is not adjusted. From the position of carriers is an effort to minimize the cost of ensuring the transport of the shipment. Of the variable costs, fuel costs represent the highest share. This is up to 30 percent of the total cost. This means that carriers are looking for the option of fuel price with the lowest price. In relation to excise duty, the term excise duty refund can be encountered in some EU countries. This is a procedure where, by Member States refund a part of the excise duty to a foreign carrier so as to motivate it to draw fuel on its territory. The state has the advantage of obtaining excise tax revenue at least at the minimum rate and the carrier refuelling at a lower price by Hautzinger (1984).
The disadvantage in this case is the state in which the carrier would, under other conditions, draw fuel, which loses all the revenue from the excise duty. The purpose of this paper is to identify the excise refund procedure in each country and to verify the hypothesis that excise refund affects tax revenues in other countries. The paper also proposes a solution for uniform arrangements for the refund of excise duty throughout the EU so as not to distort the EU single market. Some applications are simulated in the Slovak Republic.

\section{Overview of conditions of excise tax on mineral oils.}

Since 2010, the EU Member States are obliged to comply with the minimum level of taxation of excise duties on mineral oils under two legal standards. The first is Council Directive 2003/96 / EC of 27 October 2003 restructuring the Community framework for the taxation of energy products and electricity. The second piece of legislation is Council Directive 2004/74 / EC of 29 April 2004 amending Directive 2003/96 / EC as regards the possibility for certain Member States to apply provisional exemptions or reductions in respect of energy products and electricity taxation. The standard was adopted because of a transition period where countries did not have to immediately apply the minimum level of taxation. This was intended for States where the minimum rates laid down in Directive 2003/96 / EC would create serious economic and social difficulties and could have an adverse effect on nationals and national economies. Member 
States such as Cyprus, the Czech Republic, Estonia, Hungary, Latvia, Lithuania, Malta, Poland, Slovenia and the Slovak Republic could apply the transitional period. At present, no Member State can apply this transitional period and must comply with a minimum level of taxation for diesel excise duty of $€ 330 / 1000$ liters.

The mineral oil excise duty shall be based on the quantity of mineral oil expressed in liters at $15^{\circ} \mathrm{C}(\mathrm{l})$ or in kilograms $(\mathrm{kg})$ or the amount of energy contained therein, expressed in gigajoules (GJ) Holguín et al. (2005).

Although the EU directive sets a minimum tax rate, individual states apply their own level of taxation in their territory by Fernández et al. (2003). Figure 1 shows a comparison of the variations in excise duty rates in individual EU countries and its year-on-year change between 2017 and 2018. The highest tax rates are applied in Sweden, the United Kingdom, Italy and France. The lowest tax rates are applied in Bulgaria, Estonia, Luxembourg and Poland. The level of excise duty in all EU countries is shown in Figure 1.

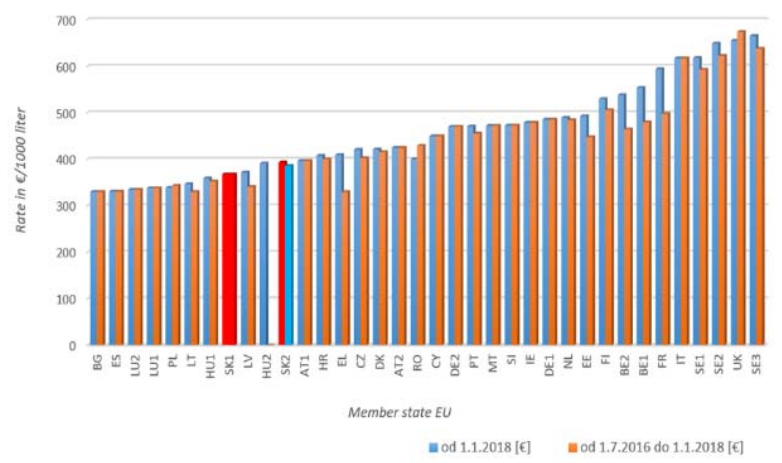

Figure 1.Change in excise duty rates on mineral oils in EU Member States

Table 1. Value added tax in EU Member States

\begin{tabular}{|c|c|c|c|}
\hline Country & VAT [\%] & Country & VAT [\%] \\
\hline Luxemburg & 17 & Lithuania & 21 \\
\hline Malta & 18 & Latvia & 21 \\
\hline Germany & 19 & Netherland & 21 \\
\hline Cypress & 19 & Italy & 22 \\
\hline Romania & 19 & Slovenia & 22 \\
\hline Bulgaria & 20 & Greece & 23 \\
\hline Estonia & 20 & Ireland & 23 \\
\hline France & 20 & Poland & 23 \\
\hline Romania & 20 & Portugal & 23 \\
\hline Slovakia & 20 & Finland & 24 \\
\hline Great Britain & 20 & Denmark & 25 \\
\hline Belgium & 21 & Croatia & 25 \\
\hline Czech Republic & 21 & Sweden & 25 \\
\hline Spain & 21 & Hungary & 27 \\
\hline
\end{tabular}

Source: authors table provides an overview of VAT rates that are not unified across the EU, and rates vary from $17 \%$ (Luxembourg) to $27 \%$ (Hungary).

The price of diesel fuel in $€ /$ liter with VAT and excise tax is shown in the figure (Fig. 2). The average price of diesel in the EU was $€ 1,346$ in 2018 , with the lowest price in the EU being $€ 1,101 /$ liter and the highest at $€ 1,519$ / liter. It is particularly important to monitor the level of fuel prices in neighbouring countries. If we observe the situation in the Slovak Republic, the price level of diesel fuel was the 13th cheapest $(1,251 € /$ liter $)$, which is lower than the EU average. Neighbouring countries of the Slovak Republic have lower price, only Hungary is on the same price level. In general, it can be argued that the price of diesel is higher in the western part of the EU compared to the eastern part of the EU, with the exception of Luxembourg, which offers the lowest price of diesel throughout the EU.

Figure 2. Price of diesel fuel as of 4.3.2019 in EU

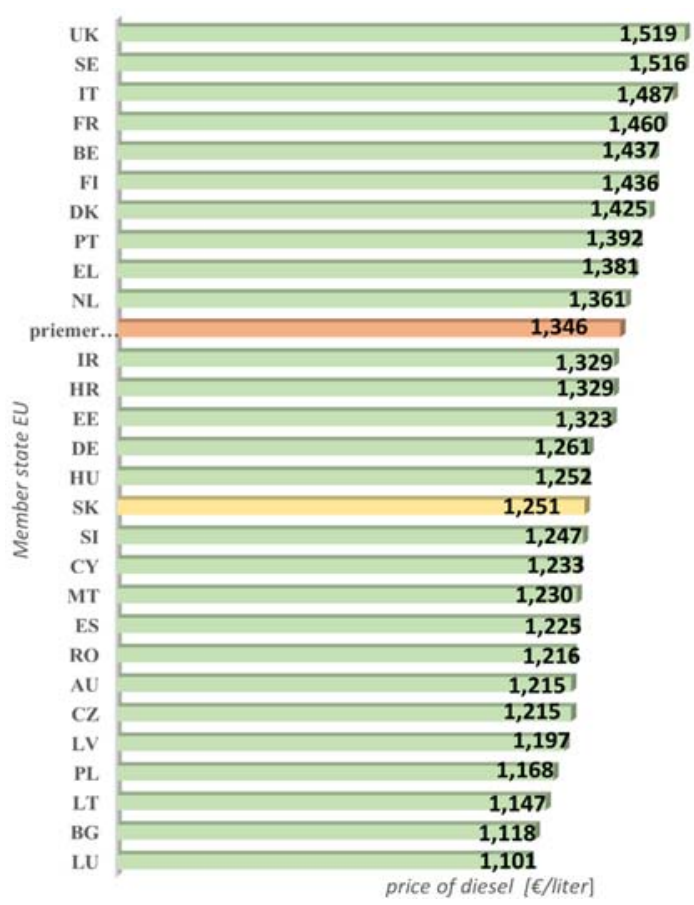

If we consider carriers registered for VAT payment, then it is necessary to monitor the price of diesel fuel without this tax (Fig. 3). In this case, the order of countries will change. E.g. the price of diesel fuel in Slovakia reaches a higher level than the average price of diesel fuel in the EU.
Most of the persons who make a demand for fuel purchases are not registered for VAT, for these persons the final price of the fuel is important, including VAT. The following 


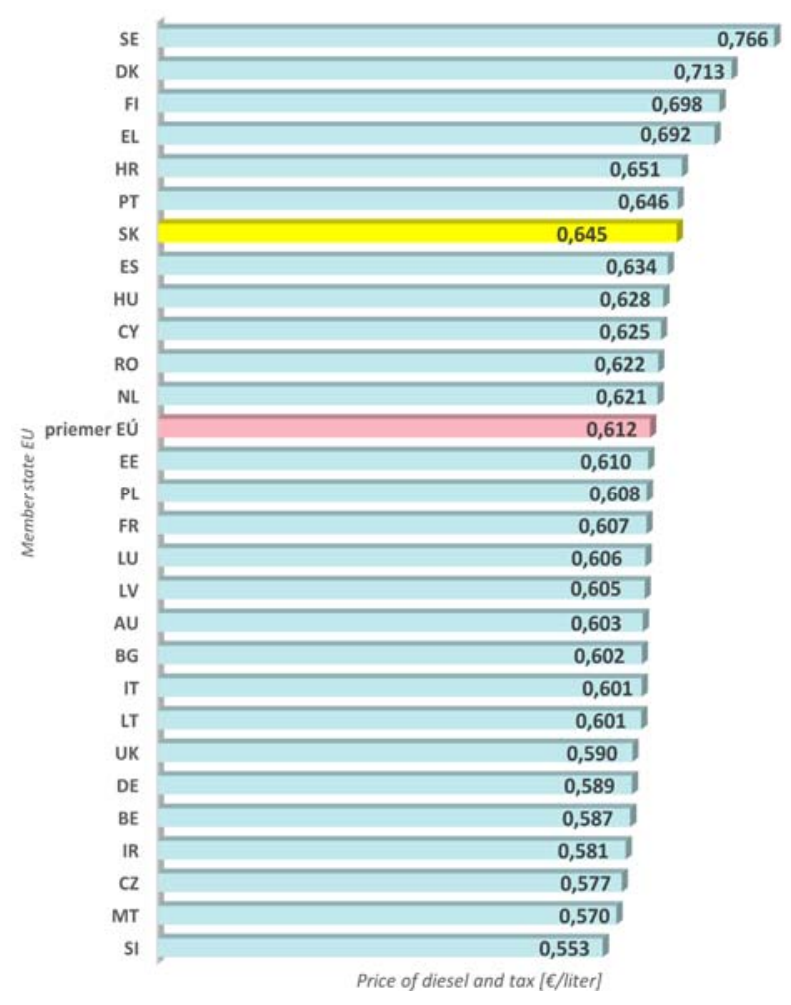

Figure 3. Price of diesel fuel excluding VAT and SD in Member States as of 4.3.2019

As the excise duty on mineral oils represents a high cost burden for carriers, in addition to optimizing the drawdown in individual countries, tax evasion related to the excise duty on mineral oils has also been reported. Hong - wei $\mathrm{Z}$ and wen-long (2004) and Gzang-ju W et al. (2016) are also addressing this issue, specifically the possibility of measuring tax evasion related to fuel sales and the possibility of detecting the amount of tax evasion related to value added tax on the fuel market in the Czech Republic. Braghin et al. (2006) and Stank et al. (2003) and Verros et al. (2005) evaluate existing standard methods used to measure tax evasion. At the same time, it has been shown that the methods are not suitable for determining the amount of tax evasion from the mineral oil tax by Kurdi et al. (2010). The authors proposed their own method for quantifying tax evasion on the basis of distributor pricing data obtained during 2012 and information obtained from a stakeholder survey. Borowiec et al. (2014) also in Montana, USA, the impact of the refund of excise duty on mineral oils on the state budget was observed, and Turkey also took into account the research, which analyzed the dynamics of fuel demand. The internalisation of externalities is also an important parameter in the field of mineral oil taxes by Richman and Moorman (2000).

As mentioned above, all EU countries have a mineral oil tax in place, accounting for about half of the net fuel price. Taxes are paid at the time of fuel purchase because of fast, easy and cheap collection. It should be noted that the mission of the tax is also to internalize all externalities caused by transport. It is possible that in some states externalities may arise than in another state, which may affect the amount of this tax. If mineral oil taxes were to be designed as an instrument for internalising all external effects, fuel should not be taxed at the same amount in each (EU) country, many congestions and accidents in the US and the UK. Several authors have addressed this issue, such as Vargo et al. (2004) and Debski et al- (2012). If the same territory is driven by a freight vehicle registered in two different countries, the same conditions should apply to both vehicles. Negatives that the tax should cover include air pollution, congestion, accidents, noise and climate change associated with greenhouse gas emissions. The mineral oil tax can be considered as a perfect tool for internalising the external costs of $\mathrm{CO} 2$ emissions, because $\mathrm{CO} 2$ emissions are closely related to fuel consumption. Accordingly, several countries advocate taxes on mineral oils for environmental reasons.

\section{Research on excise tax refunds in the EU}

Given that excise tax revenue is a national budget revenue, EU Member States strive to achieve maximum tax collection on their own territory. One option is tax refund as a means of motivating the use of fuel in the national territory. The following section provides an overview of the possibility of refunding part of the excise duty on mineral oils. These are vehicles with a payload of over $7.5 \mathrm{t}$, or vehicles of categories M2 and M3, i.e. buses. The excise duty on mineral oils can be refunded:

\section{Belgium}

In Belgium, part of the excise duty will be reimbursed in the case of refuelling with vehicles with a payload of over $7.5 \mathrm{t}$. Refunds are available up to 3 years after the date of withdrawal, but only if the client has a valid license. A copy of the RITA (TRP / VIT internal program) license must also be provided due to the need for the card number. The minimum annual refundable amount of TRP / VIT is $€ 260$, quarterly $€ 1,000$. Treasury documents are not acceptable.

\section{France}

Refunds are for vehicles with a payload of over 7.5 tons and for buses. The condition of TRP / VIT is that the carrier has to refill at least 5600 liters every six months. Treasury documents are not acceptable.

\section{Italy}

Particulars of excise duty can be refunded when refuelling with vehicles with a payload of over $7.5 \mathrm{t}$ and buses. An application is always required two years after the period. Treasury documents are not acceptable.

\section{Slovenia}

The reimbursement of part of the excise duty concerns the refuelling of diesel vehicles with a payload of over 7.5 tonnes and for buses. At least 6,500 litres per year are required. Cash receipts are only allowed if all details are given and paid by card. 


\section{Spain}

In Spain, refunds are granted for vehicles over $7.5 \mathrm{t}$ and buses.

\section{Hungary}

It is possible to refund the excise duty on mineral oils if we use diesel fuel with vehicles with a payload of over $7.5 \mathrm{t}$ and buses. The refundable amount is HUF 7.00 / litre. Treasury documents are not acceptable.

The table (Table 2) shows the current rates of excise duty for countries where refunds are possible. By comparison, we find that Belgium has the highest return chance. and Hungary has the lowest refund amount. All rates are set by the customs offices in the countries concerned and by the competent European authorities.

Excise duty refunds may be up to 24 eurocent per liter, but carriers must reckon that excise tax refunds will only be made under certain conditions, eg. registration in a given country for the purpose of refunding excise duty, using fuel cards to a specific vehicle registration number, or according to the amount of liters consumed in a particular period.

Table 2. Country excise rates applicable to international transport

\begin{tabular}{|c|c|c|}
\hline \multicolumn{2}{|c|}{ Country } & Rate $€$ /liter \\
\hline \multicolumn{2}{|c|}{ Belgium } & 0,2476158 \\
\hline \multirow{2}{*}{ France } & Truck & 0,1775 \\
\cline { 2 - 3 } Autobusy & 0,2175 \\
\hline \multicolumn{2}{|c|}{ Italy } & 0,21418000 \\
\hline \multicolumn{2}{|c|}{ Slovenia } & 0,06272 \\
\hline Spain & 0,048 \\
\hline \multicolumn{2}{|c|}{ Hungary } & 7 HUF $/ 1-0,02 *$ \\
\hline
\end{tabular}

exchange rate of 04.03.2019

Source: authors

In the following part of the article we will also look at other states within the EU group. The table (Table 2) shows the excise duty on gas oil in the EU Member States .

When applying a refund, conditions arise in which some persons are charged at a different rate in a particular territory than others. States are trying to create conditions for entrepreneurs who would otherwise use fuel abroad to draw fuel on their territory.

\section{Research on the impact of excise tax refunds on transport companies}

The authors of the article conducted a research focused on Slovak carriers operating international road transport. Fuel costs can be classified as the highest variable cost items in road transport. Depending on the classification of transports, in particular as regards long-distance or short-distance transport, they may amount to up to $40 \%$ of the total annual cost. These costs can be influenced by the carrier in several ways, eg.:

- Selecting fuel suppliers;
- optimization of fuel consumption due to different fuel prices abroad

- the possibility of refunding excise duty on diesel in selected countries.

In the latter case, the possibility of reimbursement of part of the excise duty paid on diesel fuel would be able to reduce fuel costs. This subchapter evaluates the obtained data whether the possibility of cost reduction is also used by carriers in the Slovak Republic

In order to find out the situation in the Slovak Republic among carriers carrying goods or passengers within the EU on the topic of refunding excise duty on diesel fuel, the authors conducted a survey. The carrier's e-mail addresses have been obtained through the register of carriers on the website of the single road transport information system. Not all carriers provide a contact email in the carrier register, or the email address was invalid or the addresses did not receive mail. As a result, 300 emails were sent to carriers established in the Slovak Republic. Some have also taken into account the number of vehicles where the authors have focused on those who have indicated that they have licenses for more than 10 vehicles. Research has found that $17 \%$ of carriers are using a refund of excise duty from abroad.

Carriers that reimburse excise duty also use fuel in countries with significantly higher diesel prices than in the Slovak Republic. The figure below shows the proportion of countries from which carriers most frequently reimburse excise duty. Up to $31 \%$ of carriers reimburse excise duty from Belgium and $25 \%$ from Slovenia. At the same time, the diesel price in Belgium is the 5th highest price of diesel in the EU, yet carriers are refueling in that country (which size vehicles could transit without fueling), since the refund of excise duty state is getting below the EU level.

\section{State of refund}

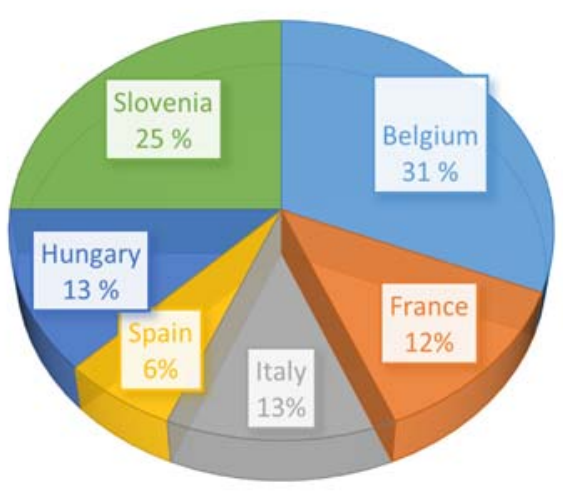

Figure 4. Answer the question about the refund location

The authors also found out how much money is reimbursed annually from the state. Slovak carriers most reimburse excise duty from Belgium (Figure 5). On average, carriers reimburse up to $75.000 €$ a year from Belgium. 


\section{Refund amount in $€ /$ year}

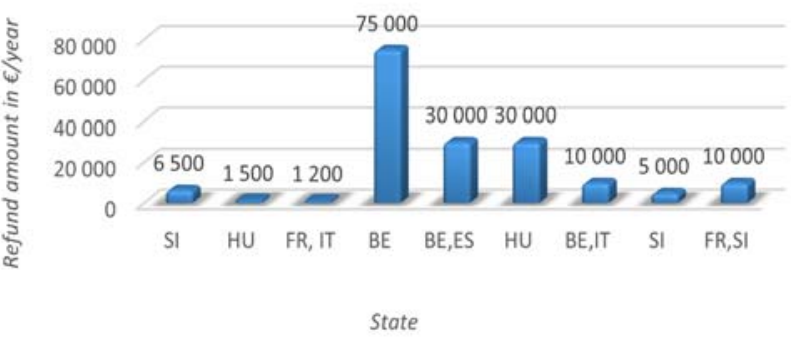

Figure 5. Answers to the amount of the refund

The states in question cannot refund excise duty below $€$ 330 per 1000 liters, which means that, at least, that part of the excise duty represents the revenue of the Belgian State budget. If, however, the refund was not allowed, the carriers would draw fueling states in another country through which the transport is carried out and in which the price of fuel is lower. If a refund were to be introduced in all EU countries,

we found out in the questionnaire what the refund system should avoid. Carriers consider the most important:

- Fast processing, quick refund, online submission

- do not impose a limit on the liters to be refunded;

- emphasize that the entire refund process is not unnecessarily complex;

- short processing time for applications,

- fast payback, online submission.

Today they do not create a level playing field in the EU common market with regard to the refund of excise duty on mineral oils. EU countries, when a neighboring state has lower diesel prices due to higher excise tax rates, encourages carriers to use fuel on their territory to get at least a minimum rate to their own budget. In our case, the average transport company in the Slovak Republic refunds from Belgium $€$ 75,000 per year, which corresponds to a diesel volume of 276,750 liters per year. If only the minimum level of excise tax remains in the Belgian state budget, the income of one Slovak company is $€ 91,300$ per year. The state budget revenue in other EU countries is reduced by this value. It should be borne in mind that with a fuel tank capacity of 750 liters, the carrier can optimize fuel consumption across the EU. It should be noted here that the system of excise refunds needs to be uniformly regulated across the EU.

\section{Conclusions}

This article deals with the issue of excise tax refunds within the EU. It points out that there are different conditions for persons operating in the EU single market. On the one hand, the EU points out that the introduction of this tax is necessary because of the burden on carriers of external transport-related costs such as accidents, emissions, noise, congestion and so on. Each EU Member State calculates excise duty rates according to its own methodology, often to meet the revenue of the state budget. It should also be noted that the EU sets a minimum level for this tax. Subsequently, in order to maximize the collection of tax in their own budgets, at the expense of tax collection in another country, states introduce tax refund systems. Tax refunds cannot be justified by reducing the external effects of transport. Excise tax refunds can be identified as a tool for distorting the EU common market. If the conditions were to be the same in the EU common market, the conditions for refunding excise duty should apply in all EU countries. Otherwise, there are conditions under which some Member States transfer tax revenues within EU Member States by means of refunds.

\section{ACKNOWLEDGEMENTS}

This publication was realized with support of Operational Program Integrated Infrastructure 2014-2020 of the project: Innovative Solutions for Propulsion, Power and Safety Components of Transport Vehicles, code ITMS 313011V334, cofinanced by the European Regional Development Fund.

\section{REFERENCES}

[1] Holguín-Veras J, Zorrilla JC, Thorson E (2005) Modeling commercial vehicle empty trips: theory and application. XVI International Symposium of Traffic and Transportation Theory (ISTTT), pp. 585-608, H. Mahmassani (Editor), Elsevier

[2] Hautzinger H (1984) The prediction of interregional goods vehicle flows: some new modeling concepts, ninth international symposium on transportation and traffic theory, VNU Science Press, pp 375-396.

[3] Fernández JE, de Cea J, Soto AO (2003) A Multi-modal supply-demand equilibrium model for predicting intercity freight flows. Transp Res Part B 37:615-640, doi: 10.1016/S01912615(02)00042-5

[4] Hong-wei Z, Wen-long W (2004) Safety analysis of over-size and over-load in road transport. J Highw Transp Res Dev 21(3):132

[5] Guang-ju W, Juan S, Bing-nan G (2016) Analysis of changes in the new version of GB 1589. AUTO SCI-TECH 4:24-29

[6] Considerations of policy for perfecting road freight transport market management. J Highw Transp Res Dev 28(2):154-158

[7] Debski, H., Koszalka, G., Ferdynus, M.: Application of FEM in the analysis of the structure of a trailer supporting frame with variable operation parameters. Eksploatacja i Niezawodnosc-Maintenance and Reliability. 14, 107-114 (2012)

[8] Braghin, F., Cheli, F., Melzi, S., Resta, F.: Tyre wear model: validation and sensitivity analysis. Meccanica 41, 143-156 (2006)

[9] Stank, T.P., Goldsby, T.J., Vickery, S.K., Savickie, K.: Logistics service performance: Estimating its influence on market share. Journal of business logistics, vol. 24, no. 1, 27-55 (2003)

[10] Bowersox, D.J., Closs D.J., Cooper M.B.: Supply Chain Logistics Management, McGraw-Hill/Irwin, New York, (2002)

[11] Verros, G., Natsiavas, S., Papadimitriou, C.: Design optimization of quarter-car models with passive and semi-active 
suspensions under random road excitation. J. Vib. Control 11 581-606 (2005)

[12] Kurdi, O., Rahman, R.A.: Finite element analysis of road roughness effect on stress distribution of heavy duty truck chassis. Int. J. Technol. 1, 57-64 (2010)

[13] Borowiec, M., Rysak, A., Betts, D.H., Bowen, C.R., Kim, H.A., Litak, G.: Complex response of the bistable laminated plate: multiscale entropy analysis. Eur. Phys. J. Plus 129, 211 (2014)

[14] Richman, J.S., Moorman, J.R.: Physiological time-series analysis using approximate entropy and sample entropy. Am. J. Physiol. Heart Circ. Physiol. 278, H2039-H2049 (2000)

[15] Vargo, S. L., Lusch, R. F.: Evolving to a new dominant logic for marketing. Journal of Marketing, no. 68, January, 1-17 (2004) 